\title{
EMISI UDARA INDUSTRI PENGOLAHAN KELAPA SAWIT DI KABUPATEN ROKAN HILIR
}

\author{
Yeeri Badrun
}

\begin{abstract}
ABSTRAK
Penelitian ini dilakukan April 2009 di 3 (tiga) lokasi pabrik pengolahan kelapa sawit (PKS), yang berada di Kecamatan Sinembah Kabupaten Rokan Hilir Provinsi Riau. Analisis terhadap gas buang berupa NOx, SOx, H2s, partikel (partikulat), opassitas dan Pb yang dilakukan pada lokasi boiler dengan cara menghisap gas yang keluar dan selanjutnya dilakukan analisis di laboratorium. Hasil penelitian menunjukkan bahwa PKS PT Dharma Wungu Guna telah mencemari lingkungan sekitarnya dengan kandungan gas hidrogen sulfida 45,4 mg/Nm3 dan telah melewati bakumutu dibandingkan 2 PKS lainnya. Untuk partikulat dan tingkat opasitas yang dihasilkan dari ketiga PKS masih memenuhi baku mutu yang ditetapkan sedangkan partikel Sulfure Diokside (SO2) dan Lead (Pb) tidak terdeteksi sehingga diperkirakan tidak akan mencemari lingkungan sekitarnya.
\end{abstract}

Kata Kunci: Emisi, Sawit, Udara

\section{PENDAHULUAN}

Pemanfaatkan sumberdaya alam untuk pembangunan merupakan salah satu cara untuk memperkuat perekonomian. Konsekuensi yang terjadi dengan adanya pemanfaatan sumberdaya alam ini adalah adanya perubahan pada lingkungan hidup. Aktivitas industri pengolahan kelapa sawit (PKS) merupakan salah satu cara pemanfaatan sumber daya alam dalam industri kelapa perkebunan sawit. Kegiatan ini akan memberikan perubahan-perubahan terhadap lingkungan. Perubahan yang terjadi berupa perubahan bentuk ataupun perubahan fungsi secara cepat maupun secara perlahanlahan. Perubahan-perubahan ini ada yang berdampak positif dan ada juga yang berdampak negatif terhadap lingkungan.

Salah satu dampak lingkungan dari kegiatan pengoperasian pabrik Pengolahan Kelapa Sawit (PKS) adalah penurunan kualitas udara. Adanya buangan gas dari aktifias PKS akan mengakibatkan perubahan dari kualitas udara di lingkungan sekitarnya.

Tingkat pencemaran udara dapat diukur dari perubahan kualitas udara tersebut serta dapat ditetapkan pada suatu periode dan tempat tertentu. Kualitas adalah suatu numerik yang ditetapkan berdasarkan pada suatu kondisi tertentu dengan mempertimbangkan berbagai faktor yang mempengaruhi lingkungan udara. Kualitas udara mengalami perubahan pada suatu periode tertentu sesuai dengan interaksi komponen lingkungan. Dengan adanya kegiatan baru dalam lingkungan timbul interaksi baru antara satu kegiatan atau lebih dengan satu atau lebih komponen lingkungan. Interaksi tersebut menyebabkan saling pengaruh mempengaruhi dan pada gilirannya akan menimbulkan dampak positif maupun negatif.

Pengkajian kualitas udara perlu dilakukan karena adanya potensi akumulasi bahan pencemar dalam udara yang dipengaruhi oleh aktifitas yang menyangkut terjadinya perubahan lingkungan seperti perindustrian. Dari hasil kajian tersebut, kemudian dapat dikaji dan disimpulkan bagaimana performa perusahaan dalam melaksanakan pengelolaan dan pemantauan lingkungan hidup di sekitar areal usaha.

Tujuan dari penelitian ini adalah Mengetahui kondisi kualitas udara emisi dan ambien di lingkungan pabrik pengolahan kelapa sawit (PKS) di Kabupaten Rokan 
Hilir. Mengevaluasi tingkat pencemaran udara emisi dan ambien sebagai akibat dari aktivitas pabrik pengolahan kelapa sawit (PKS) di Kabupaten Rokan Hilir.

Hasil penelitian ini diharapkan memberikan gambaran kondisi kualitas udara yang ada di lingkungan perkebunan dan pabrik pengolahan kelapa sawit (PKS) di Kabupaten Rokan Hilir.

\section{METODOLOGI PENELITIAN}

Kajian dan pengujian pencemaran udara telah dilaksanakan pada bulan April 2009 di 3 (tiga) lokasi pabrik pengolahan kelapa sawit (PKS), yaitu di PKS Balai Jaya PT. Sinar Perdana Caraka (SPC), PKS Sie. Meranti (PT Perkebunan Nusantara III), dan PKS PT. Dharma Wungu Guna yang berada di Kecamatan Sinembah Kabupaten Rokan Hilir Provinsi Riau (Gambar 1).

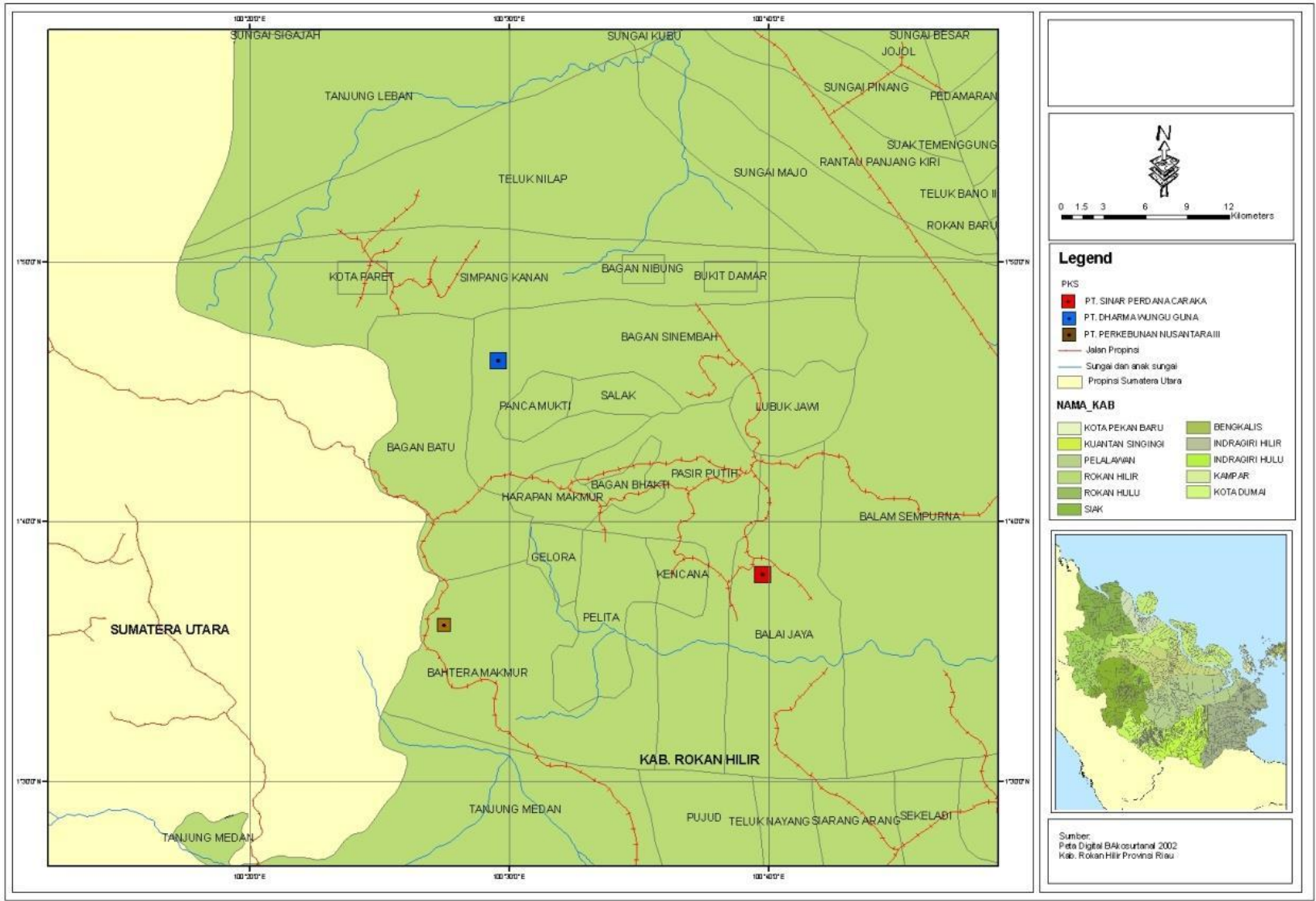

Gambar 1. Lokasi Penelitian

\section{PROSEDUR PENELITIAN}

Analisis terhadap gas buang berupa Pengambilan sampel udara emisi terdiri dari: $\mathrm{NO}_{x}, \quad \mathrm{SO}_{x}, \mathrm{H}_{2} \mathrm{~s}$, partikel (partikulat), opassitas dan $\mathrm{Pb}$ yang dilakukan pada lokasi boiler. Pengambilan sampel dilakukan dengan menghisap gas yang keluar dan ditampung dalam peralatan khusus berbentuk tabung kaca yang kedap udara. Selanjutnya dilakukan analisis dengan alat gas khromatografi dan spektrofotometri.
Titik Gas buang pengambilan sampel dihisap dengan menggunakan kompresor yang terlebih dahulu melewati alat penyaring yang disebut dengan impaktor bertingkat. Besar nilai kisaran partikel yang didapat akan terbagi dengan sendirinya pada setiap ukuran diameter saringan. Selanjutnya sampel siap dianalisis di laboratorium

Pengukuran logam berat terhadap gas buang yang timbul dilakukan dengan cara menganalisis sampel yang didapat dari 
impaktor bertingkat. Sampel terlebih dahulu diradiasi dengan menggunakan suatu sumber neutron. Inti atom unsur-unsur yang berada dalam sampel tersebut akan menangkap neutron dan berubah menjadi radioaktif. Setelah paparan radiasi neutron dianggap cukup, sampel dikeluarkan dari sumber neutron. Sampel tersebut sekarang mengandung unsur-unsur yang memancarkan sinar-sinar radioaktif. Sinar $\gamma$ atau sinar gamma yang dipancarkan oleh berbagai unsur dalam contoh dapat dianalisis secara spektrometri- $\gamma$. Analisis kualitatif setiap unsur dilakukan berdasarkan pada pengukuran energi sinar- $\gamma$, sedangkan analisis kuantitatif dilakukan dengan mengukur intensitasnya. pengukuran energi sinar- $\gamma$, sedangkan analisis kuantitatif dilakukan dengan mengukur intensitasnya.

$$
\mathrm{SO}_{2}=\frac{(\mathrm{A}-\mathrm{Ao})(1000)(\mathrm{Bs})}{\mathrm{Vr}} \times \mathrm{D} \mu \mathrm{g} / \mathrm{m}^{3}
$$

Keterangan,

$$
\begin{aligned}
\mathrm{A} & =\text { absorbansi contoh } \\
\mathrm{Ao} & =\text { absorbansi blanko } \\
\mathrm{Bs} & =\text { faktor kalibrasi } \mathrm{SO}_{2}(\mu \mathrm{g} / \mathrm{unit} \\
\mathrm{absorbansi}) & \\
\mathrm{Vr}= & \text { volume udara terkoreksi } \\
& \left(\mathrm{t}=25^{\circ} \mathrm{C}, \mathrm{P}=70 \mathrm{~mm} \mathrm{Hg}\right) \text { dalam } \\
& \text { liter } \\
\mathrm{D}= & \text { faktor pengencer. }
\end{aligned}
$$

b. Nitrogen dioksida $\left(\mathrm{NO}_{2}\right)$ menggunakan metode Greiss-Saltzman

Prinsip pengukuran, $\mathrm{NO}_{2}$ di udara ambien diserap dalam larutan penyerap yang mengandung asam sulfanilat dan N-(1-Naphtyl)-Ethylene Diamin Dihidrochloride membentuk senyawa berwarna muda. Intensitas warna yang terjadi diukur dengan alat spektrofotometer pada panjang gelombang $550 \mathrm{~nm}$.
Konsentrasi $\mathrm{NO}_{2}$ di udara ditentukan terlebih dahulu dengan rumus:

$\mathrm{NO}_{2}=\frac{(0.01)(\mathrm{A})(\mathrm{Y})}{(\mathrm{S})(\mathrm{V})} \mu \mathrm{g} \mathrm{m}^{3}$

Keterangan,
$\mathrm{A}=$ nilai absorbansi dari contoh (yang telah dikoreksi)
$\mathrm{Y}=$ volume larutan penyerap $\mathrm{NO}_{2}$ yang digunakan $(25 \mathrm{ml})$
$\mathrm{S}=$ kemiringan kurva kalibrasi (absorbansi per $\mu \mathrm{g} / \mathrm{ml}$ )
$\mathrm{V}=$ volume udara contoh yang telah dikoreksi $\left(\mathrm{m}^{3}\right)$
S $\sim \quad 0.62 / \mu \mathrm{g} / \mathrm{ml}$

c. Timah hitam $(\mathrm{Pb})$ dengan metode AAS (Atomic Absorbtion Spectrometer)

Analisis konsentrasi partikel $\mathrm{Pb}$ di udara dilakukan dengan metode Gravimetrik dan interaksi pengabuan dengan cara membuat ekstrak dari 0,5 gram hasil gilingan dalam labu Kjeldahl dan menambaHCannya ke dalam larutan pengekstrak yang terdiri atas $5 \mathrm{ml} \mathrm{HNO}_{3}$ (70\%) dan $5 \quad \mathrm{ml} \quad \mathrm{HClO}_{4} \quad(70 \%)$. Campuran didestruksi dengan pemanasan $100^{\circ} \mathrm{C}$ sehingga uap coklat dari nitrat hilang, kemudian dipanaskan pada suhu $200^{\circ} \mathrm{C}$ hingga larutan jernih. Larutan jernih ditambah air suling hingga $10 \mathrm{ml}$. Kemudian pengukuran kandungan $\mathrm{Pb}$ dalam partikel debu dibaca dengan menggunakan AAS pada panjang gelombang 283,3 nm.

Kandungan $\mathrm{Pb}$ (ppm) dihitung dengan rumus:

$$
\text { Kandungan } \mathrm{Pb}=\frac{\text { Absorbansi contoh } \times f a \times f b}{\text { Gram sampel }} \mathrm{ppm}
$$

Keterangan:

$f a=1 /$ kemiringan kurva

kalibrasi

$f b=$ faktor pengenceran 
d. Partikel dengan menggunakan metode Gravimetry

Analisis sampel dilakukan sebagai berikut:

- Kertas fiber filter dioven sebelum digunakan

- Kertas fiber filter kosong ditimbang (dicatat nilainya)

- Kertas filter dioven kembali

- Kertas fiber filter yang berisi debu ditimbang

Konsentrasi Total Parikel Terspensi (TSP) ditetapkan dengan formula:

$$
T S P=\frac{(W f-W i) x 10^{6}}{V t}
$$

Keterangan: $\quad$ TSR $=$ konsentrasi $\quad$ TSP $\left(\mu \mathrm{g} / \mathrm{m}^{3}\right)$

$$
W f=\text { berat akhir filter }(\mathrm{g})
$$

$W i=$ berat awal filter $(\mathrm{g})$ udarasampel $\left(\mathrm{m}^{3}\right)$

$V t=$ total volume

$$
10^{6}=\text { konversi } \mathrm{g} \mathrm{ke} \mu \mathrm{g}
$$

Data-data yang diperoleh akan dianalisi dan disajikan dalam bentuk tabular dan grafik. Masing-masing parameter kualitas udara emisi dan udara ambien dibahas dan dibandingkan berdasarkan dengan Keputusan Menteri Negara Lingkungan Hidup No. 7 Tahun 2007 tentang Baku Mutu Udara Emisi Sumber Tidak Bergerak dan Kepmen LH No Kep-13/MENLH/3/1995

\section{HASIL DAN PEMBAHASAN}

Hasil pengujian sampel udara emisi di lokasi boiler pabrik kelapa sawit di daerah kajian pada saat pengukuran dapat dilihat pada uraian di bawah ini.

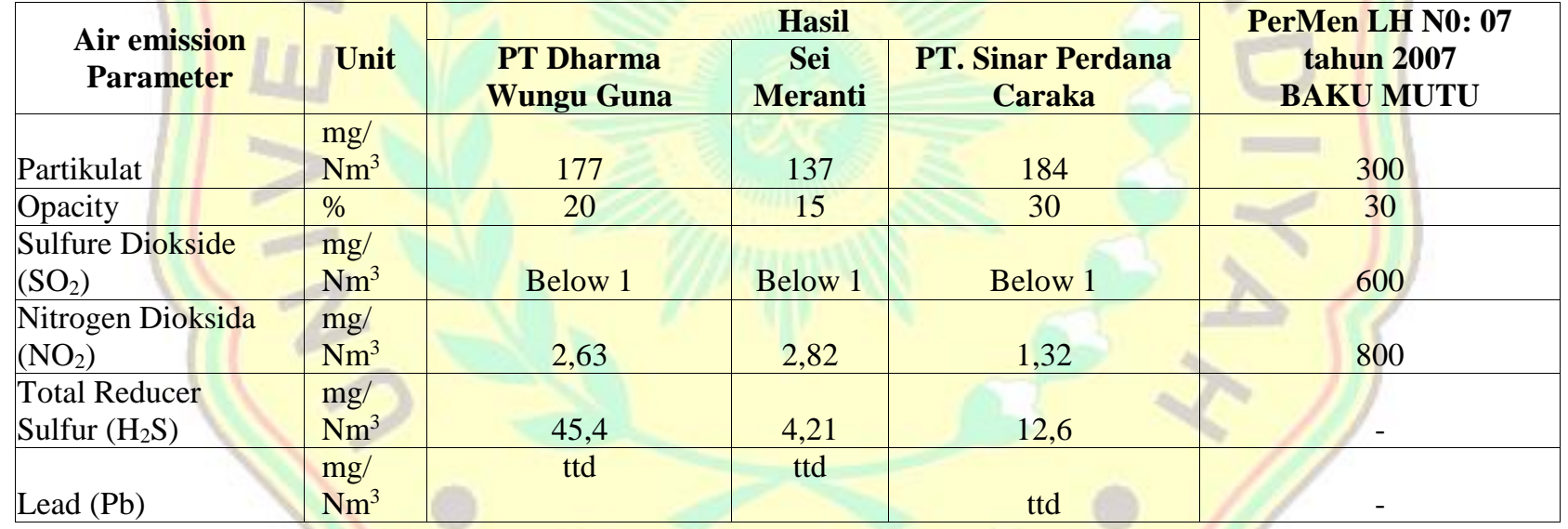

ttd: Tidak terdeteksi
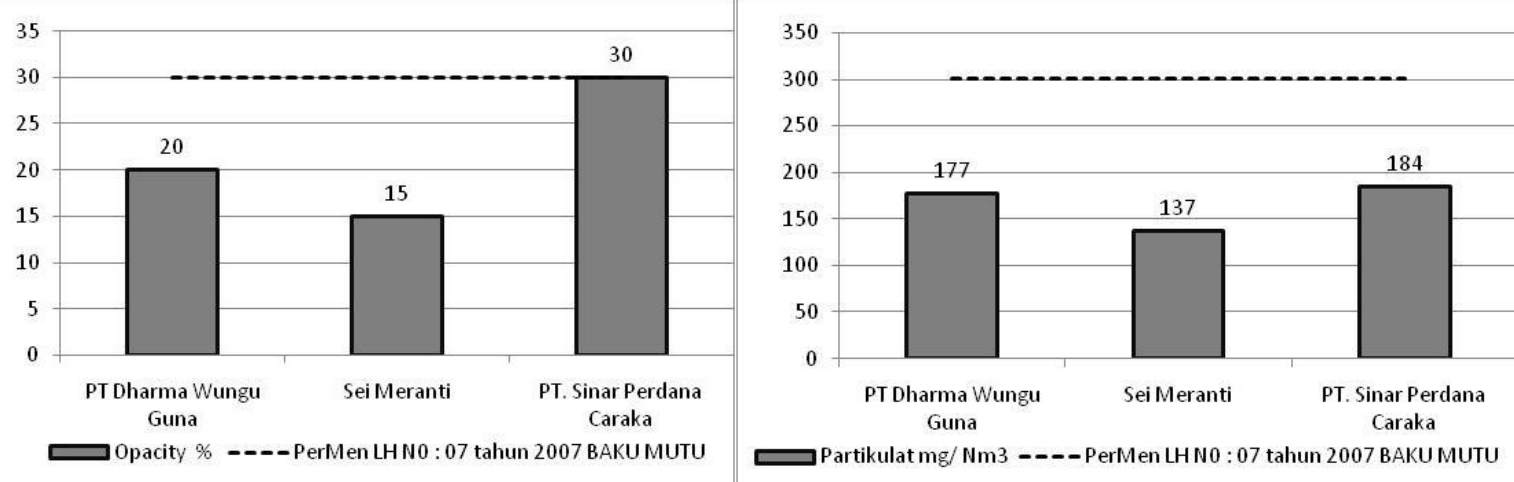

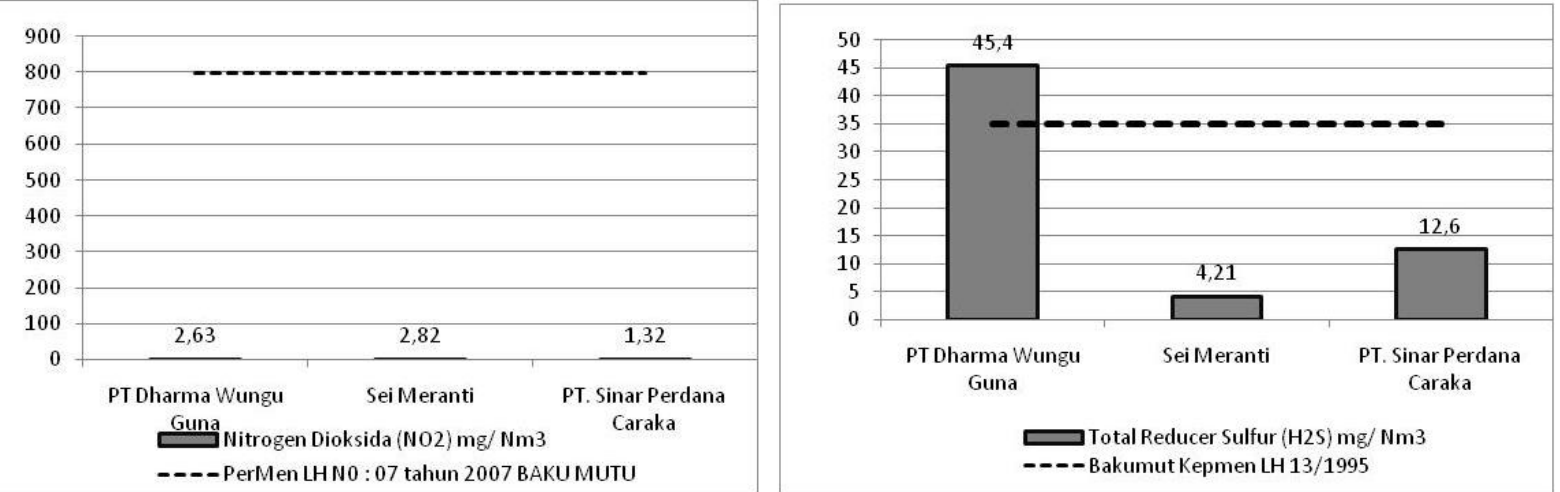

Gambar 2. Grafik Perbandingan Hasil Pengukuran Kualitas Udara Emisi yang dihasilkan dari 3 (tiga) boiler pabrik Kelapa Sawit di Kabupaten Rokan Hilir

Hasil pengukuran Kualitas Udara Emisi yang dihasilkan dari Boiler 3 (tiga) Pabrik Kelapa Sawit di Kabupaten Rokan Hulu menunjukkan/masih memenuhi standar bakumutu berdasarkan Permen LH No 7 tahun 2007.

Pada grafik dari gambar 1 diatas terlihat bahwa partikulat yang dihasilkan dari ke tiga PKS yang diamati masih berada dibawah nilai baku mutu yang ditetapkan. Konsentrasi yang paling rendah terdapat pada PKS Sie Meranti (137 mg/ $\mathrm{Nm}^{3}$ ) selanjutnya di ikuti PKS PT Dharma Wungu Guna $\left(177 \mathrm{mg} / \mathrm{Nm}^{3}\right)$ dan yang tertinggi terdapat pada PKS Sinar Perdana Caraka $\left(184 \mathrm{mg} / \mathrm{Nm}^{3}\right)$. Partikulat dari sumber emisi pabrik dapat berupa debu atau partikelpartikel kecil padatan dan droplet cairan yang terdapat dalam jumlah tinggi di udara emisi. Sumber partikel yang utama adalah pembakaran bahan bakar dari sumbernya, diikuti oleh proses-proses industri (Fardiaz, 1992).

Debu merupakan produk-produk pembakaran terutama asap dari pembakaran tidak sempurna. Dari hasil pengujian sampel didapatkan bahwa konsentrasi partikulat udara emisi di lokasi boiler PKS hampir mendekati ambang batas yang ditetapkan. Jika kondisi tersebut dibiarkan terus tanpa ada pengelolaan kualitas udara emisi yang baik, maka besar kemungkinannya partikulat dalam udara emisi di daerah kajian ini konsentrasinya akan semakin meningkat, bahkan dapat melebihi batas maksimal baku mutu lingkungan yang ditetapkan pemerintah. Jika kondisi ini terjadi, maka partikulat di udara ambien akan semakin meningkat konsentrasinya sehingga besar kemungkinan akan mengakibatkan terjadinya pencemaran udara oleh partikulat.

Berdasarkan tingkat opasitasnya, terlihat sebaran konsentrasinya hampir sama dengan parameter partikulat. Konsentrasi yang paling rendah terdapat pada PKS Sie Meranti (15\%) selanjutnya di ikuti PKS PT Dharma Wungu Guna (20 \%) dan yang tertinggi terdapat pada PKS Sinar Perdana Caraka (30\%). Opasitas emisi dari PKS Sinar Perdana Caraka telah barada pada nilai ambang batas berdasarkan bakumutu yang ditetapakan pemerintah. Opasitas adalah tingkat kekeruhan atau kegelapan suatu gas dan berhubungan korelatif dengan total partukulat. Dengan demikian warna gas buangan dari PKS Sinar Perdana Caraka lebih gelap dibandingkan PKS Dharma Wungu Guna dan Sie Meranti. Hasil pengukuran opasitas ini sejalan dengan hasil pengukuran partikulat.

Gas hidrogen sulfida $\left(\mathrm{H}_{2} \mathrm{~S}\right)$ yang di ukur pada ketiga PKS yang diteliti menunjukkan bahwa PT Dharma Wungu Guna melepaskan gas hidrogen sulfida paling tinggi sebesat $45,4 \mathrm{mg} / \mathrm{Nm}^{3}$ dibandingkan ke dua PKS Lainnya, dimana PT Sinar Perdana 
Caraka melepaskan gas hidrogen sulfida sebesar $12,6 \mathrm{mg} / \mathrm{Nm}^{3}$ sedangkan Sei Meranti hanya sebesar $4,21 \mathrm{mg} / \mathrm{Nm}^{3}$. Konsentrasi gas hidrogen sulfida yang dilepaskan PT Dharma Wungu Guna telah melewati nilai ambang batas berdasarkan baku mutu yang ditetapkan dalam Kepmen LH No 13 tahun 1995. Gas hidrogen sulfida $\left(\mathrm{H}_{2} \mathrm{~S}\right)$ mempunyai bau yang tidak enak serta memberikan gangguan selaput lendir pada saluran cerna dan saluran nafas yang dapat memberikan gangguan pada hidung dan mata.

Untuk parameter sulfur dioksida dan timbal $(\mathrm{Pb})$ serta nitrogen dioksida $\left(\mathrm{NO}_{2}\right)$, masing-masing PKS menghasilkan dalam konsentrasi yang sangat kecil dan bahkan tidak terdeteksi. Oleh karena itu ketiga parameter ini tidak akan berdampak terhadap lingkungan diskitarnya. Timbal ini sangat berbahaya terhadap kesehatan manusia, mulai dari yang kadarnya rendah yang mengakibatkan gangguan pendengaran, penurunan IQ, gangguan pertumbuhan dan fungsi penglihtan sampai yang kadarnya tinggi yang dapat mengakibatkan anemia, kerusakan otak bahkan dapat mengakibatkan kematian. Oksida nitrogen seperti NO dan NO2 berbahaya bagi manusia. Penelitian menunjukkan bahwa NO2 empat kali lebih beracun daripada NO. NO2 bersifat racun terutama terhadap paru. Kadar NO2 yang lebih tinggi dari 100 ppm dapat mematikan sebagian besar binatang percobaan dan $90 \%$ dari kematian tersebut disebabkan oleh gejala pembengkakan paru (edema pulmonari). Kadar NO2 sebesar 800 ppm akan mengakibatkan $100 \%$ kematian pada binatang-binatang yang diuji dalam waktu 29 menit atau kurang. Pemajanan NO2 dengan kadar 5 ppm selama 10 menit terhadap manusia mengakibatkan kesulitan dalam bernafas.

\section{KESIMPULAN}

Dari hasil analisis beberapa gas emisi yang diukur pada 3 (tiga) PKS di wilayah administrasi Kabupaten Rokan Hilir dapar disimpulkan bahwa:

1. PKS PT Dharma Wungu Guna telah mencemari lingkungan sekitarnya dengan kandungan gas hidrogen sulfidan yang sangat tinggi $\left(45,4 \mathrm{mg} / \mathrm{Nm}^{3}\right)$ melebihi nilai ambang batas dari baku mutu yang telah ditetapkan (35 45,4 $\mathrm{mg} / \mathrm{Nm}^{3}$ berdasarkan Kepmen LH No 13 tahun 1995). Besarnya konsentrasi akan mencemari kualitas udara disekitarnya.

2. Untuk partikulat dan tingkat opasitas yang dihasilkan dari ketiga PKS masih memenuhi baku mutu yang ditetapkan sehingga diperkirakan belum mencemari kualitas udara disekitarnya.

3. Untuk partikel Sulfure Diokside (SO2) dan Lead $(\mathrm{Pb})$ yang diukur dari ketiga PKS tidak terdeteksi sehingga diperkirakan tidak akan mencemari lingkungan sekitarnya.

\section{DAFTAR PUSTAKA}

Asdep Urusan pengendalian Pencemaran Emisi Sumber Bergerak Deputi Bidang Pengendalian Pencemaran Lingkungan Kementrian Negara Lingkungan Hidup. 2008. Proceeding of Fuel Quality Monitoring in 10 Big Cities in Indonesia.

Badan Lingkungan Hidup Jawa Timur. 2007. Polusi Surabaya Lebih Parah dari Jakarta . Bapedal.

Diko, Handono. 2002. Permodelan Dinamis Dan Peramalan Kebutuhan Bahan Bakar Gas (BBG) 10 Tahun Mendatang Di Wilayah Surabaya. Tugas Akhir S1 Jurusan Teknik Industri, Institut Teknologi Sepuluh Nopember. Surabaya 
Hamdan, Dani. 2002. Model Dinamis Mengenai Hujan Asam di Kotamadya Bandung. Tugas Akhir S1 Jurusan Teknik Lingkungan, Institut Teknologi Bandung. Bandung

Slamet, Lilik. 2002. Skenario Emisi CO2 di Indonesia. Prosiding Seminar Nasional Pemanasan Global dan Perubahan Global . Fakta, Mitigasi, dan Adaptasi. Pusat Pemanfaatan
Sains Atmosfer dan Iklim LAPAN. lilik@bdg.lapan.go.id

Utami, E. A. (2009). Modeling Supply Chain Contracts in Pharmaceutical Industry Using System Dynamics Approach. Thesis S2 Jurusan Teknik Industri, Institut Teknologi Sepuluh Nopember. Surabaya.

Wardhana, Wisnu Arya. 2004. Dampak Pencemaran Lingkungan. Yogyakarta: Penerbit ANDI. 